\title{
Oxidative stress in the latissimus dorsi muscle of diabetic rats
}

\author{
K.L.D. De Angelis ${ }^{1}$, \\ I.A. Cestari ${ }^{3}$, J. Barp ${ }^{1}$, \\ P. Dall'Ago ${ }^{1}$, \\ T.G. Fernandes ${ }^{1}$, \\ S. Llesuy ${ }^{1}$ and \\ M.C. Irigoyen ${ }^{1,2}$
}

P.I. Homem de Bittencourt ${ }^{1}$,

A. Belló-Klein ${ }^{1}$, A.A. Belló ${ }^{1}$,

\author{
${ }^{1}$ Laboratório de Fisiologia Cardiovascular, Departamento de Fisiologia, \\ Instituto de Ciências Básicas da Saúde, Universidade Federal do Rio Grande do Sul, \\ Porto Alegre, RS, Brasil \\ 2Unidade de Hipertensão e Divisão de Experimentação, and \\ ${ }^{3}$ Divisão de Bioengenharia, Instituto do Coração, Faculdade de Medicina, \\ Universidade de São Paulo, São Paulo, SP, Brasil
}

\section{Correspondence \\ M.C. Irigoyen \\ Unidade de Hipertensão e \\ Divisão de Experimentação \\ Instituto do Coração, HC-FMUSP \\ Av. Enéas de Carvalho Aguiar, 44 \\ 05043-000 São Paulo, SP \\ Brasil \\ Fax: + 55+11-3069-5048 \\ E-mail: hipirigoyen@incor.usp.br}

Presented at the XV Annual Meeting of the Federação de Sociedades de Biologia Experimental, Caxambu, MG, Brazil, August 23-26, 2000.

Research supported by CN Pq, CAPES, and FAPERGS. Publication supported by FAPESP.

Received April 12, 2000 Accepted July 26, 2000

\section{Abstract}

The purpose of the present study was to investigate the effects of experimental diabetes on the oxidant and antioxidant status of latissimus dorsi (LD) muscles of male Wistar rats $(220 \pm 5 \mathrm{~g}, \mathrm{~N}=11)$. Shortterm ( 5 days) diabetes was induced by a single injection of streptozotocin (STZ, $50 \mathrm{mg} / \mathrm{kg}$, iv; glycemia $>300 \mathrm{mg} / \mathrm{dl}$ ). LD muscle of STZdiabetic rats presented higher levels of thiobarbituric acid reactive substances (TBARS) and chemiluminescence $(0.36 \pm 0.02 \mathrm{nmol} / \mathrm{mg}$ protein and $14706 \pm 1581 \mathrm{cps} / \mathrm{mg}$ protein) than LD muscle of normal rats $(0.23 \pm 0.04 \mathrm{nmol} / \mathrm{mg}$ protein and $7389 \pm 1355 \mathrm{cps} / \mathrm{mg}$ protein $)$. Diabetes induced a $92 \%$ increase in catalase and a $27 \%$ increase in glutathione S-transferase activities in LD muscle. Glutathione peroxidase activity was reduced (58\%) in STZ-diabetic rats and superoxide dismutase activity was similar in LD muscle of both groups. A positive correlation was obtained between catalase activity and the oxidative stress of LD, as evaluated in terms of TBARS $(r=0.78)$ and by chemiluminescence $(r=0.89)$. Catalase activity also correlated inversely with glutathione peroxidase activity $(\mathrm{r}=0.79)$. These data suggest that an increased oxidative stress in LD muscle of diabetic rats may be related to skeletal muscle myopathy.

Reactive oxygen species (ROS) have been implicated in the pathophysiology of a large number of diseases and this role has been attributed to their high reactivity and deleterious effects on cell structures $(1,2)$.

Mechanisms that contribute to the high level of oxidative stress in diabetes may include not only increased non-enzymatic glycosylation (glycation) and auto-oxidative glycosylation but also metabolic stress in sorbitol pathway activity, changes in the levels of inflammatory mediators and in the status of

\section{Key words}

- Streptozotocin-diabetes

- Latissimus dorsi muscle

- Oxidative stress

- Catalase

- Glutathione antioxidant defense systems (1). Although diabetes has profound effects on the biochemical, morphological and contractile properties of skeletal and cardiac muscle (3), the importance of oxidative stress and its antioxidant adaptations in skeletal muscle of diabetic rats has been less studied.

Latissimus dorsi (LD) muscles are used in cardiomyoplasties. Studies have demonstrated that the improvement in cardiac and hemodynamic function in cardiomyoplasty is currently confronted by the occurrence of 
muscle degeneration and necrosis that compromise contractile bioassist (4). However, selection criteria for this type of treatment do not exclude diabetic patients. The purpose of the present study was to investigate the effects of experimental streptozotocin-induced diabetes on the oxidant and antioxidant process in LD muscle.

Male Wistar rats from the Animal House of the Federal University of Rio Grande do Sul, Porto Alegre, RS, Brazil, weighing 190$250 \mathrm{~g}$, had free access to food and water. One group $(\mathrm{N}=6)$ of rats was made diabetic with a single $i v$ injection of streptozotocin (STZ, $50 \mathrm{mg} / \mathrm{kg}$ ) dissolved in citrate buffer, $\mathrm{pH} 4.5$. Rats were fasted overnight before STZ injection. A second group $(\mathrm{N}=5)$ was injected with citrate buffer and maintained as a normal control group.

After 5 days of STZ-induced diabetes, the animals were killed with a blow to the head, $1 \mathrm{ml}$ of blood was collected into tubes containing a drop of heparin saline (Produtos Roche Químicos e Farmacêuticos, Rio de Janeiro, RJ, Brazil), and the LD muscles were isolated and removed. The blood samples were centrifuged for $10 \mathrm{~min}$ at 3000 $g$ and plasma was collected for later glucose determination by a colorimetric enzymatic test (Boehring Institute, Mannheim, Germany).

The LD muscles were homogenized in an ultra-Turrax blender using $1 \mathrm{~g}$ of tissue per 5 $\mathrm{ml}$ of $150 \mathrm{mmol} / \mathrm{l}$ potassium chloride and 20 nmol/1 phosphate buffer, $\mathrm{pH} 7.4$, and the homogenates were centrifuged at $600 \mathrm{~g}$ for $10 \mathrm{~min}$ at $-2^{\circ} \mathrm{C}$. Proteins were assayed by measurement with the Folin phenol reagent (5).

Aliquots of LD homogenates were added to thiobarbituric acid and butanol and used for malondealdehyde (MDA) determination according to the technique of Buege and Aust (6) for thiobarbituric acid reactive substances (TBARS).

The chemiluminescence assay was carried out with an LKB Rack Beta Liquid
Scintillation Spectrometer 1215 (LKB Producter AB, Bromma, Sweden) in the outof-coincidence mode at room temperature $\left(25-27^{\circ} \mathrm{C}\right)$. The assay consists of the addition of an organic synthetic hydroperoxide to tissue sample homogenates and the observation of the response. Hydroperoxides are highly unstable. They can react with membrane lipids, initiating the lipid peroxidation process and yielding singlet oxygen and excited carbonyls. These species are excited and can stabilize by means of light emission. The supernatants were diluted in $140 \mathrm{mM}$ $\mathrm{KCl}$ and $20 \mathrm{mM}$ phosphate buffer, $\mathrm{pH}$ 7.4, and added to glass tubes which were placed in scintillation vials; $3 \mathrm{mM}$ tert-butylhydroperoxide was added and chemiluminescence was determined up to the maximal level of emission (7).

Catalase (CAT) activity was measured by monitoring the decrease in $\mathrm{H}_{2} \mathrm{O}_{2}$ concentration spectrophotometrically over time. Aliquots of the samples were added to 50 $\mathrm{mM}$ phosphate buffer in a quartz cuvette. After zeroing the instrument, $\mathrm{H}_{2} \mathrm{O}_{2}$ was added to a final concentration of $10 \mathrm{mM}$ in $0.9 \mathrm{ml}$ and absorbance was measured at $240 \mathrm{~nm}$. The specific activity of each sample was calculated on the basis of the activity of pure CAT as described by Aebi (8).

Superoxide dismutase (SOD) activity was determined in the homogenates by measuring the inhibition of the rate of autocatalytic adrenochrome formation at $480 \mathrm{~nm}$ in a reaction medium containing $1 \mathrm{mM}$ epinephrine and $50 \mathrm{mM}$ glycine- $\mathrm{NaOH}, \mathrm{pH} 10.5$ (9).

$\gamma$-Glutamyl-cysteine-synthetase ( $\gamma$-GCS) was assayed in LD homogenized in buffer $\mathrm{A}$ $(100 \mathrm{mM}$ Tris- $\mathrm{HCl}, 150 \mathrm{mM} \mathrm{KCl}, 20 \mathrm{mM}$ $\mathrm{MgCl}_{2}, 2 \mathrm{mM}$ EDTA, and $5 \mathrm{mM}$ ß-mercaptoethanol, $\mathrm{pH}$ 8.0) by coupling ATP hydrolysis to NADH consumption via the pyruvate kinase/lactate dehydrogenase reaction (10). The reaction $\left(37^{\circ} \mathrm{C}\right)$ was monitored spectrophotometrically at $340 \mathrm{~nm}$ in buffer consisting of $1.34 \mathrm{mMNADH}, 10 \mathrm{mM}$ amine butyrate, $10 \mathrm{mM}$ sodium glutamate, $2 \mathrm{mM}$ 
phosphoenolpyruvate, $5 \mathrm{mM}$ ATP, $1.85 \mathrm{U} /$ $\mathrm{ml}$ pyruvate kinase, and $2.13 \mathrm{U} / \mathrm{ml}$ lactate dehydrogenase, $\mathrm{pH}$ 8.0.

Glutathione peroxidase (GPx) activity was measured by the method of Del Maestro (11). Sample aliquots were added to the assay mixture of $1 \mathrm{U} / \mathrm{ml}$ glutathione reductase and $2 \mathrm{mM}$ glutathione in $1 \mathrm{ml}$ phosphate buffer and the mixtures were preincubated at $37^{\circ} \mathrm{C}$ for $30 \mathrm{~min}$. Subsequently NADPH and tert-butylhydroperoxide were added to final concentrations of 155 and $580 \mu \mathrm{M}$, respectively, and the change in absorbance at 340 $\mathrm{nm}$ was recorded at regular intervals over a period of $4 \mathrm{~min}$. One enzyme unit was defined as the amount of GPx required to oxidize $1 \mu \mathrm{mol}$ NADPH in $1 \mathrm{~min}$ at $25^{\circ} \mathrm{C}$ and calculated on the basis of molar absorbance for NADPH at $340 \mathrm{~nm}$.

Glutathione S-transferase (GST) was quantified in muscle homogenates that were assayed $\left(37^{\circ} \mathrm{C}\right)$ in a buffer containing $0.2 \mathrm{M}$ sodium phosphate, $\mathrm{pH} 6.5,20 \mathrm{mM}$ reduced glutathione and $20 \mathrm{mM}$ 1-Cl-2,4-dinitrobenzene. The formation of 2,4 dinitrophenyl-Sglutathione by GST was monitored spectrophotometrically at $340 \mathrm{~nm}$ (12).

Data are reported as mean \pm SEM and the values obtained for the two groups were compared by the unpaired Student $t$-test. Correlations were determined by linear regression analysis.

All rats given STZ developed severe hy- perglycemia $(106 \pm 15$ vs $306 \pm 19 \mathrm{mg} / \mathrm{dl}$ for the diabetic group, $\mathrm{P}=0.001$ ) accompanied by a $20 \%$ decrease in body weight. At the beginning of the experiments diabetic and control rats presented similar body mass (213 $\pm 4 \mathrm{~g}$ vs $220 \pm 11 \mathrm{~g}$ ).

Homogenates of LD muscle used to evaluate in vitro lipoperoxidation presented higher oxidative stress in diabetic than in control rats. TBARS, which reflect MDA production, in LD muscle showed an increase of $56 \%$ in STZ rats as compared to normal rats (Table 1). Chemiluminescence, that reflects the balance between the pro-oxidants and antioxidants, was twice higher in diabetic than in control LD muscles (Table 1).

The activity of antioxidant enzymes in LD muscle presented different alterations in response to diabetic oxidative stress, as can be observed in Table 1. The activity of CAT, an enzyme that catalyzes the reduction of $\mathrm{H}_{2} \mathrm{O}_{2}$ to $\mathrm{H}_{2} \mathrm{O}$ and $\mathrm{O}_{2}$, was greatly increased $(92 \%)$ in LD muscle of STZ rats. The SOD enzyme, that catalyzes the dismutation of superoxide into less toxic hydrogen peroxide, presented similar activity in the LD muscle of the groups studied. Diabetic LD muscle showed higher $\gamma$-GCS activity (17.7 $\pm 1 \mu \mathrm{mol} \mathrm{min}^{-1} \mathrm{mg}_{\text {protein }}{ }^{-1}$ ) than control LD muscle $\left(12.6 \pm 1.4 \mu \mathrm{mol} \mathrm{min}^{-1} \mathrm{mg}\right.$ protein $\left.{ }^{-1}\right)$, indicating increased glutathione synthesis. Diabetes induced an increase (27\%) in GST activity and a decrease (58\%) in GPx activ-

\begin{tabular}{|c|c|c|c|}
\hline \multicolumn{4}{|c|}{ Data are reported as mean \pm SEM. $* \mathrm{P}<0.05$ compared to control (Student t-test). NS, Not significant. } \\
\hline & Control & Diabetic & $\mathrm{P}$ \\
\hline TBARS (nmol/mg protein) & $0.23 \pm 0.04$ & $0.36 \pm 0.02 *$ & 0.03 \\
\hline Chemiluminescence (cps/mg protein) & $7389 \pm 1355$ & $14706 \pm 1581 *$ & 0.03 \\
\hline Catalase (pmol min-1 mg protein-1) & $8.7 \pm 1$ & $16.7 \pm 1.5^{*}$ & 0.03 \\
\hline Superoxide dismutase (U/mg protein) & $7.2 \pm 1.1$ & $5.3 \pm 0.3$ & NS \\
\hline Glutathione S-transferase ( $\mathrm{nmol} \mathrm{min-1} \mathrm{mg}$ protein-1) & $72.7 \pm 6$ & $92.5 \pm 5^{*}$ & 0.03 \\
\hline Glutathione peroxidase ( $\mu \mathrm{mol} \mathrm{min}^{-1} \mathrm{mg}$ protein-1) & $45.1 \pm 5$ & $18.9 \pm 1.5^{*}$ & 0.03 \\
\hline
\end{tabular}


Figure 1 - Positive correlation obtained by linear regression in latissimus dorsi (LD) muscle of control and diabetic groups between: A, Thiobarbituric acid reactive substances (TBARS, nmol/ mg protein) and catalase activity (CAT, pmol min $^{-1}$ mg protein ${ }^{-1}$ ); $\mathrm{B}$, chemiluminescence (cps/mg protein) and CAT activity (pmol $\mathrm{min}^{-1} \mathrm{mg}$ protein ${ }^{-1}$ ), and C, CAT activity (pmol min $^{-1} \mathrm{mg}$ protein ${ }^{-1}$ ) and glutathione peroxidase activity (GPx, $\mu \mathrm{mol} \mathrm{min}^{-1} \mathrm{mg}$ protein $^{-1}$ ). ity. These enzymes catalyze the detoxification of peroxides and the reduction of $\mathrm{H}_{2} \mathrm{O}_{2}$ by reduced glutathione, respectively (Table 1).

A positive correlation was obtained by linear regression between oxidative stress and CAT activity in LD muscle from the groups studied, with higher CAT activity at higher levels of oxidative stress, as evaluated by TBARS $(\mathrm{r}=0.78, \mathrm{P}=0.05)$ (Figure $1 \mathrm{~A})$ or by chemiluminescence $(\mathrm{r}=0.89, \mathrm{P}=$ 0.001 ) (Figure 1B). CAT activity was also inversely correlated with GPx activity in LD muscle from all groups $(\mathrm{r}=0.79, \mathrm{P}=0.004)$ (Figure 1C).

The major findings of the present experiments are that LD muscle from 5-day STZdiabetic rats showed increased oxidative
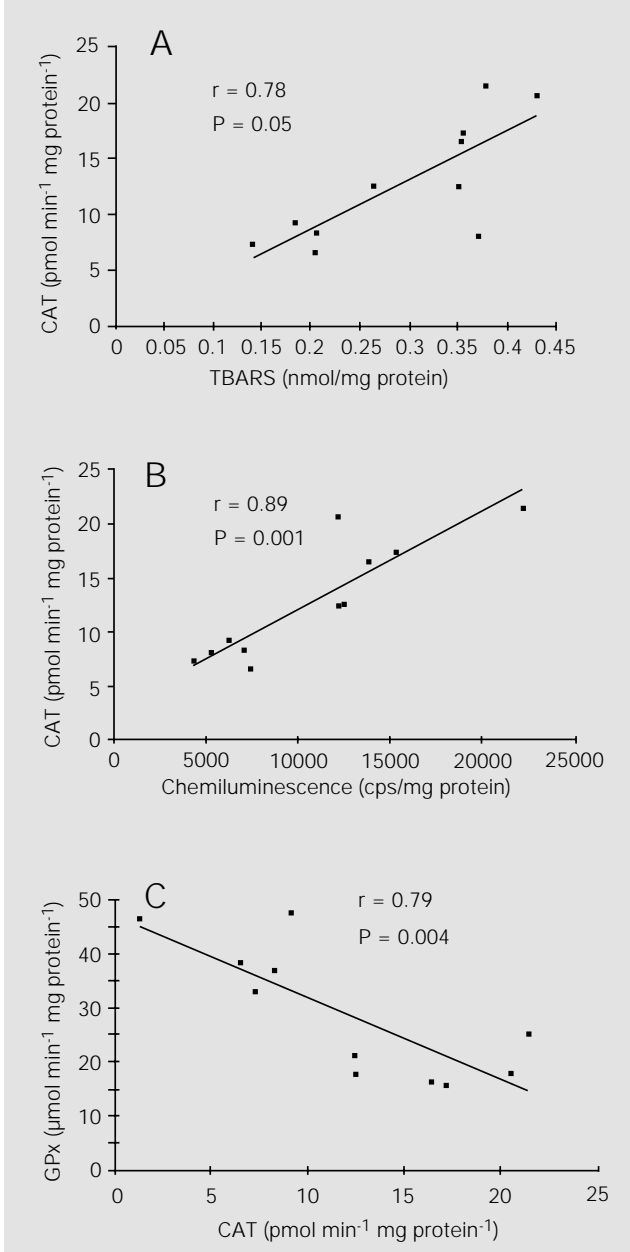

stress, indicated by TBARS and chemiluminescence, and adaptations in antioxidant enzymes.

This is the first experiment carried out to study oxidative stress in LD muscle. The present results are in agreement with previous studies showing increased levels of oxidative stress in red blood cells, kidney, liver, brain, and heart in diabetes $(1,2,13,14)$. A probable mechanism explaining these changes is related to the increased glucose concentration. Several diabetic complications including myopathy have been attributed to hyperglycemia stimulation of the polyol pathway (1-3). Moreover, it has been demonstrated that aldose reductase inhibitor (ARI) treatment has a marked beneficial effect on skeletal muscle contractile performance in experimental diabetes, thus implicating the polyol pathway as a causative factor in diabetic myopathy. The reduction of tetanic tension output in the extensor digitorum longus muscle was related to polyol pathway activity, since it was prevented by ARI treatment. Combined insulin and ARI therapy produced an improvement of the contractile properties of soleus muscle that was more marked than the improvement caused by each agent alone (3). Furthermore, Cameron and Cotter (15) demonstrated a decrease in ROS damage in STZ-diabetic rats treated with ARI, confirming that hyperglycemia is related to the activation of the polyol pathway leading to increased oxidative stress.

The causes of the increased pro-oxidant activity in diabetes are multifactorial and not completely understood. Probably, hyperglycemia can lead to both a rise in ROS production and to the attenuation of free radical scavenging compounds (2). In a ROS review, Baynes (1) concluded that diabetes with complications is associated with increased chemical modification of protein and lipids. Hyperglycemia leads to protein glycation, glucose auto-oxidation and fatty acid oxidation, which may contribute to increased ROS generation. Antioxidant en- 
zymes appear to be important for cell defense against oxidative damage. Changes in antioxidant concentration occur according to the tissue studied, and these alterations may be related to the capacity of these tissues to adapt to oxidative stress (2). Kakkar et al. (13) observed high levels of TBARS in pancreas, heart and blood of diabetic rats. Catalase activity was increased in liver, heart and blood, but not in kidneys. The GPx enzyme presented higher activity in pancreas and kidneys of STZ animals and SOD activity was increased in liver, heart and pancreas. The above results are an example of differences in the adaptive responses of tissues to the diabetic process. Moreover, there are time-course changes in antioxidant enzymes in the same tissue (14).

In the present experiments we observed higher CAT activity in LD muscle from shortterm diabetic rats compared to normal rats. The increase in muscle CAT, located in microperoxisomes, may reflect increased levels of fatty acyl CoA oxidase that initiates the $\beta$-oxidation of fatty acids in peroxisomes $(16,17)$. Reinforcing the importance of CAT as an antioxidant tool to block the increase in skeletal muscle diabetic oxidative stress, we observed a positive correlation between TBARS levels and CAT activity $(r=0.78)$ and also between chemiluminescence and CAT activity $(r=0.89)$, suggesting that oxidative stress induced by $\mathrm{H}_{2} \mathrm{O}_{2}$ leads to elevation of CAT activity.

In the present study there was no change in SOD activity in LD muscle from diabetic rats, suggesting a less intense effect of diabetes on SOD than on CAT activity. Similar data, increased CAT and unchanged SOD, were observed in skeletal muscles of 80-day STZ-diabetic rats (17). These results may indicate an important role of peroxisomes in the adaptation of LD muscle to hyperglycemia. Other data showing an increase or a decrease in SOD activity may be due to differences in experimental design or in the tissue evaluated (2).

The increase in the formation of glutathione, evidenced by higher $\gamma$-GCS activity, suggests a role for glutathione in the defense of cells against oxidative stress. In fact, the activity of GST, a nonspecific peroxide scavenger, was increased in LD muscle, probably helping with cell detoxification. However, GPx activity was reduced in muscle from diabetic rats. A similar reduction in GPx activity was observed in most studies on experimental diabetes (2). The reduction in GPx activity associated with enhanced oxidative stress in diabetic muscle observed here may be related to increased $\mathrm{H}_{2} \mathrm{O}_{2}$ levels (18). Although we did not quantify $\mathrm{H}_{2} \mathrm{O}_{2}$ production, the increase in CAT activity, a specific $\mathrm{H}_{2} \mathrm{O}_{2}$ scavenger, may indicate an increase in $\mathrm{H}_{2} \mathrm{O}_{2}$ formation in diabetic LD muscle. The inverse correlation between CAT and GPx activities $(r=0.79)$ reinforces the occurrence of this possibility in skeletal muscle of diabetic rats.

The increase in oxidative stress has been associated with inactivation of voltage-dependent calcium channels and of plasma membrane $\mathrm{Ca}^{2+}$ ATPase (19) and $\mathrm{Na}^{+} \mathrm{K}^{+}$ ATPase (3). Moreover, the increase in type and frequency of skeletal muscle mitochondrial DNA deletions in diabetic patients may be related to oxidative damage by ROS (20). All these data seem to indicate that oxidative stress plays an important role in diabetic myopathy.

We have previously observed that reduced tetanic force in LD muscle of shortterm diabetic rats (21) was associated with reduced $\mathrm{Na}^{+} \mathrm{K}^{+}$ATPase and $\mathrm{Ca}^{2+}$ ATPase activities. In addition, abnormalities in skeletal muscle function were detected in patients with chronic heart failure (4). These data suggest that muscle bioassistance should be carefully analyzed in diabetic heart failure patients. 


\section{References}

1. Baynes J W (1991). Role of oxidative stress in development of complications in diabetes. Diabetes, 40: 405-412.

2. Van Dam PS, Van Asbeck BS, Erkelens W, Marx J J M, Gispen WH \& Bravenboer B (1995). The role of oxidative stress in neuropathy and other diabetic complications. Diabetes Metabolism Reviews, 11: 181192.

3. Cameron NE, Cotter MA \& Robertson $\mathrm{S}$ (1990). Changes in skeletal muscle contractile properties in streptozotocin-induced diabetic rats and role of polyol pathway and hypoinsulinemia. Diabetes, 39: 460-465.

4. Chachques J C, Marino J P, Lajos P, Zegdi R, D'Attellis N, Fornes P, Fabiani J N \& Carpentier A (1997). Dynamic cardiomyoplasty: clinical follow-up at 12 years. European J ournal of Cardio-Thoracic Surgery, 12: $560-568$

5. Lowry OH, Rosebrough NJ, Farr AL \& Randall RJ (1951). Protein measurement with the Folin phenol reagent. J ournal of Biological Chemistry, 193: 265-275.

6. Buege J A \& Aust SD (1978). Microsomal lipid peroxidation. Methods in Enzymology, 52: 302-310.

7. Gonzalez Flecha B, Llesuy $S \&$ Boveris A (1991). Hydroperoxide-initiated chemiluminescence: an assay for oxidative stress in biopsies of heart, liver, and muscle. Free Radical Biology and Medicine, 10:
93-100.

8. Aebi H (1984). Catalase in vitro. Methods in Enzymology, 105: 121-126.

9. Misra HP \& Fridovich I (1972). The role of superoxide anion in the autooxidation of epinephrine and simple assay for superoxide dismutase. J ournal of Biological Chemistry, 247: 3170-3175.

10. Seelig GF \& Meister A (1984). Glutathione biosynthesis; $\gamma$-glutamylcysteine synthetase from rat kidney. J ournal of Biological Chemistry, 259: 379-390.

11. Del Maestro R (1985). Oxidative enzymes in tissue homogenates. In: Greenwald RA (Editor), CRC Handbook of Methods for Oxygen Radical Research. CRC Press Inc., Boca Raton, FL, 294-296.

12. Mannervik B \& Guthenberg C (1981). Glutathione transferase (human placenta). Methods in Enzymology, 77: 231-237.

13. Kakkar R, Kalra J, Mantha SV \& Prasad K (1995). Lipid peroxidation and antioxidant enzymes in diabetic rats. Molecular and Cellular Biochemistry, 151: 113-119.

14. Kakkar R, Mantha SV, Kalra J \& Prasad K (1996). Time course study of oxidative stress in aorta and heart of diabetic rat. Clinical Science, 91: 441-448.

15. Cameron NE \& Cotter MA (1997). Metabolic and vascular factors in the pathogenesis of diabetic neuropathy. Diabetes, 46: S31-S37.

16. Christie KN (1979). Catalase in skeletal muscle fibers. J ournal of Histochemistry and Cytochemistry, 27: 814-819.

17. Lammi-Keefe CJ , Swan PB \& Hegarty PVJ (1984). Evidence for increased peroxidative activity in muscles from streptozotocin-diabetic rats. Proceedings of the Society for Experimental Biology and Medicine, 176: 27-31.

18. Arnaiz SL, Travacio $M$, Monserrat AJ, Cutrín J C, Llesuy S \& Boveris A (1997). Chemiluminescence and antioxidant levels during peroxisome proliferation by fenofibrate. Biochimica et Biophysica Acta, 1360: 222-228.

19. Viner RI, Hühmer AFR, Bigelow DJ \& Schöneich C (1997). The oxidative inactivation of sarcoplasmatic reticulum $\mathrm{Ca}^{2+}$ ATPase by peroxynitrite. Free Radical Research, 24: 243-259.

20. Liang P, Hughes V \& Fukagawa NK (1997). Increased prevalence of mitochondrial DNA deletions in skeletal muscle of older individuals with impaired glucose tolerance: possible marker of glycemic stress. Diabetes, 46: 920-923.

21. D'Avila K, Cestari IA, Bittencourt PIH, Leirner AA \& Irigoyen MC (1997). Changes in latissimus dorsi isometric contractile properties in streptozotocin-induced diabetic rats. Artificial Organs, 2: 485 (Abstract). 